\title{
Fiber Optic Temperature Sensor (U)
}

by

D. Rabold

Westinghouse Savannah River Company

Savannah River Site

Aiken, South Carolina 29808

DOE Contract No. DE-AC09-89SR18035

This paper was prepared in connection with work done under the above contract number with the U.S.

Department of Energy. By acceptance of this paper, the publisher and/or recipient acknowledges the U.S. Government's right to retain a nonexclusive, royalty-free license in and to any copyright covering this paper, along with the right to reproduce and to authorize others to reproduce all or part of the copyrighted paper.

\section{MASTER}




\section{DISCLAIMER}

This report was prepared as an account of work sponsored by an agency of the United States Government. Neither the United States Government nor any agency thereof, nor any of their employees, makes any warranty, express or implied, or assumes any legal liability or responsibility for the accuracy, completeness. or usefulness of any information. apparatus, product, or process disclosed, or represents that its use would not infringe privately owned rights. Refereace herein to any specific commercial product, process, or service by trade name, trademark, manufacturer, or otherwise does not necessarily constitute or imply its endorsement, recommendation, or favoring by the United States Government or any agency thereof. The views and opinions of authors expressed herein do not necessarily state or reflect those of the United States Government or any agency thereof.

This report has been reproduced directly from the best available copy.

Available to DOE and DOE contractors from the Office of Scientific and Technical Information, P. O. Box 62, Oak Ridge. TN 37831; prices available from (615) $576-8401$.

Available to the public from the National Technical Information Service. U. S. Deparment of Commerce, 5285 Port Royal Rd., Springfield, VA 22161 
Fiber Optic Temperature $S$

Patrick E. O'Rourke, Principal Invos

\section{Westinghouse}

Savannah River Technology Cenver
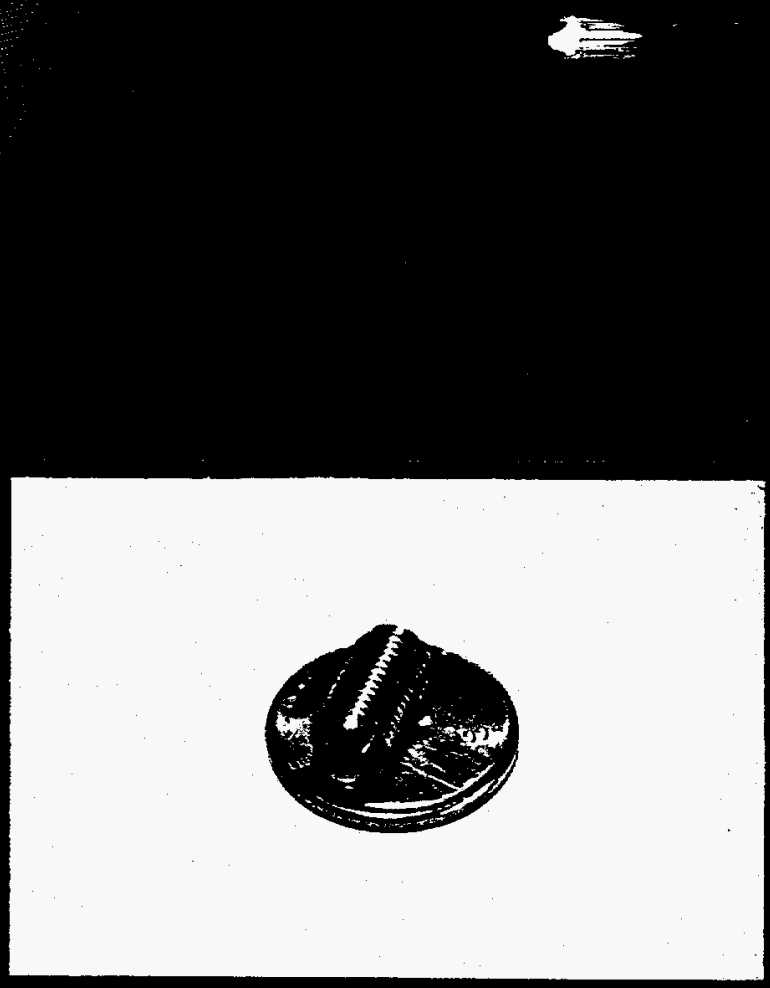


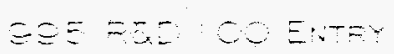

\section{Fiber Optic Temperature Sensor}

FATAOE. E. ORCUFE. FRINCHFL NESTIGATOF

On the cover:

Accurate and dependable wide-range temperature measurements in hazardous, corrosive, and high electromagnetic field environmen: economically and safely with this innovative optical-based temperature sensor. 
1. Submitting organization: Westinghouse Savannah River Company

Address:

Savannah River Technology Center

City/State/Zip/Country: Aiken, SC 29808 (USA)

Submitter's name:

Patrick E. O'Rourke

Phone/Fax:

803/725-2173; 803/725-4707

Affirmation: I affirm that all information submitted as a part of, or supplemental to, this entry is a fair and accurate representation of this product.

submitter's signature: Patuck $\sum$ Chamhe

2. Joint entry with

Address:

City/State/Zip/Country:

Submitter's name:

Phone/Fax:

\section{Product Name: Fiber Optic Temperature Sensor}

4. Briefly describe what the entry is.

This optical-based temperature sensor provides accurate and stable remote measurement of on-line temperatures in hazardous environments and in environments having high ambient electromagnetic fields without the need for calibration of individual probes and sensors.

5. When was this product first marketed or available for order? (month/year)

February 1994

6. Inventor or Principal Developer: Patrick E. O'Rourke, Ph.D

Position: Fellow Scientist

Phone: $803 / 725-6413$
Organization: Westinghouse Savannah River Company Fax: 803/725-6223

7. Product price: Probe: $\$ 300$ per measurement point

Common Instrumentation: Approximately $\$ 8,000$

If the price is proprietary, list it and check here:

8. Do you hold any patents on this product?

Do you have any patents pending?

Yes $\otimes \quad$ No

Do others hold patents on this product or a similar product line?

Yes $\boldsymbol{\nabla} \quad$ No $\square$

Yes $\square \quad$ No $\otimes$ 
9. Describe your product's primary function.

Our new optical temperature sensor system measures temperatures from $-200^{\circ} \mathrm{C}$ to $600^{\circ} \mathrm{C}$ safely and accurately even in extremely hazardous, corrosive, and high electro-magnetic field environments. It is ideal for use in these conditions because its glass-based technology is inherently immune to electrical interference and corrosion. Because there is no need to recalibrate individual sensors, operator and technician safety is greatly enhanced, as the need for their repeated exposure to field conditions is eliminated.

Our probes are made from largely non-conducting and low thermal conductance material, resulting in high stability and low susceptibility to interference, and in increased operator safety. Our transmission system is simple and reliable, and our analytical methods give highly accurate and repeatable results over a wide range of temperatures. Further, optical cables have a much higher information-carrying capacity and are far less subject to interference than electrical conductors.

Conventional methods of temperature measurement (thermocouples, RTDs, thermistors, and the like) may produce erroneous readings due to electromagnetic interference and from degradation in the operating environment. Further, these devices must be individually calibrated and re-calibrated periodically, requiring the process measurement to be interrupted, and introducing calibration and measurement error.

Other types of optical temperature sensors and measuring systems are commercially available, but all are subject to inaccuracies due to poor resolution, drift, temperature effects in multi-fiber transmission lines, and limited temperature ranges. Also, measurements can be affected by thermal contraction and expansion of the probes, requiring calibration of each individual probe before use.

The keys to the success of our system are the behavior of the sensor with temperature and the techniques by which we analyze the spectra transmitted from the probe.

The optical temperature sensor can be either made of glass doped with rare earths or of fluids, such as a mixture of $\mathrm{D}_{2} \mathrm{O}$ and $\mathrm{H}_{2} \mathrm{O}$. Light of the appropriate frequency(ies) is transmitted to the sensor via a single fiber fiber-optic cable (possibly using a multiplexer), and the reflected or transmitted light from the sensor is then routed back to a spectrometer system. The output of the spectrometer is analyzed using programs and algorithms we have developed to provide a realtime temperature readout (Figure 1).

Temperature measurements from our system are accurate and reliable. A neodymium-doped borosilicate glass sensor can measure temperatures from $-196^{\circ} \mathrm{C}$ to $600^{\circ} \mathrm{C}, \pm 0.5 \mathrm{C}^{\circ}$. Repeatability of $0.2 \mathrm{C}^{\circ}$ is typical.

Because the temperature response is a function of the material, and is determined in advance of installation, recalibration is unnecessary, saving considerable time, cost and reducing operator exposure. Sensors and probes are not subject to degradation under severe conditions: they are durable, corrosion-resistant, heat-resistant, and impervious to electrical or magnetic aivrference. Optical fibers and multiplexers allow remote monitoring of sensors in inaccessible or hazardous locations, and the optical signal is transmitted with low attenuation without the need for prior conditioning.

Our sensors possess both temperature-dependent and temperature-independent optical characteristics. By measuring in advance both of these characteristics for a given sensor material, we can determine temperature at the sensor using algorithms which employ the ratios of these characteristics. Once we have determined the temperature characteristics of the sensor material, we use the ratio, $R$, of the temperatureindependent factor to the temperature-dependent factor to determine temperature, $T$, as a function $T=f(R)$. Then, we compute $R$ from the light transmitted back to the measuring station, and apply $f(R)$ to determine temperature. The temperature function, $f(R)$, for a given sensor material may be computed using two different methods: the absorption spectrum method and the double ratio absorbance method (Figure 2). It is most desirable to use sensor materials which result in lower-order functions to promote efficient real-time temperature display. 
10a. List your product's competitors.

The main competitor of this technology is the Luxtron Corporation, which produces a fluorescence-based detector. The Luxtron detector has a smaller temperature range and is much more susceptible to light (signal) degradation through junction and cable losses.

The other competitors are existing technologies, used by many manufacturers. They include: optical-based technologies of optical time-domain reflectometry (OTDR), absorption spectra, fluorescence intensity, and emmissivity; and electrical-based technologies of thermocouples, thermistors, and resistance temperature detectors (RTD).

10b. Supply a comparison matrix.

The comparison matrix appears on the following page.

10c. Describe how your product improves upon competitive technologies.

Our system is a great improvement upon existing methods of measuring temperature in remote or hazardous areas or processes, and in areas containing high electromagnetic interference. It combines the benefits of wide-range $\left(-200^{\circ} \mathrm{C}\right.$ to $\left.600^{\circ} \mathrm{C}\right)$, high accuracy $\left( \pm 0.5^{\circ} \mathrm{C}\right)$, and repeatability $\left(0.2 \mathrm{C}^{\circ}\right)$, with high tolerance to inhospitable environments and enhanced operator safety in a highly cost-effective approach. These combined benefits are not available with competing products or technologies. Of course, the system may be used in less severe applications as well.

All applications benefit from the elimination of the need for calibration of individual sensors and the elimination of the need for field recalibration.

Because our sensors are made of materials having low thermal conductivity, they are less likely to affect the temperature of the process itself. And, because they are made of non-electricallyconducting materials, they are virtually impervious of interference from high ambient electromagnetic fields, as are electrically-based sensors. All these features provide these practical advantages:

- higher accuracy (high resolution, low drift, low losses)

- higher reliability (simple, durable sensors and transmission lines; stable sensor technology)

- wider application (wide measurement ranges; independence of process temperature; independence from electromagnetic interference)

- reduced costs (no need to calibrate individual sensors or to recalibrate; less overall system complexity)

- increased safety (less need to enter hazardous areas to remove sensor for recalibration or replacement; fewer sensors needed to cover a wide temperature range) 
Comparison Matrix

\begin{tabular}{|c|c|c|c|c|c|c|c|c|}
\hline Feature & $\begin{array}{l}\text { Fiber Optic } \\
\text { Temperature } \\
\text { Sensor }\end{array}$ & OTDR & Fluorescence & Emnissivity & $\begin{array}{l}\text { Thermo- } \\
\text { couple }\end{array}$ & $\begin{array}{l}\text { Therm- } \\
\text { istor }\end{array}$ & RTD & Competitive Advantage \\
\hline Range & $-200^{\circ} \mathrm{C}-600^{\circ} \mathrm{C}$ & $\begin{array}{l}-40^{\circ} \mathrm{C}- \\
150^{\circ} \mathrm{C}\end{array}$ & $-40^{\circ} \mathrm{C}-300^{\circ} \mathrm{C}$ & $\begin{array}{l}200^{\circ} \mathrm{C}- \\
600^{\circ} \mathrm{C}\end{array}$ & $\begin{array}{l}-200^{\circ} \mathrm{C}- \\
1500^{\circ} \mathrm{C}\end{array}$ & $\begin{array}{l}-100^{\circ} \mathrm{C}- \\
200^{\circ} \mathrm{C}\end{array}$ & $\begin{array}{l}-200^{\circ} \mathrm{C}- \\
600^{\circ} \mathrm{C}\end{array}$ & $\begin{array}{l}\text { Reduces need for specialized } \\
\text { sensors for various temper- } \\
\text { ature ranges: one size fits all }\end{array}$ \\
\hline Accuracy & $\pm 0.5^{\circ} \mathrm{C}$ & $\pm 1^{\circ} \mathrm{C}$ & $\pm .5^{\circ} \mathrm{C}$ & $\pm .5^{\circ} \mathrm{C}$ & $\pm .5^{\circ} \mathrm{C}$ & $\pm .5^{\circ} \mathrm{C}$ & $\pm .5^{\circ} \mathrm{C}$ & No compromise on accuracy \\
\hline Resolution & $0.1 C^{\circ}$ & $.5 \mathrm{C}^{\circ}$ & $.10^{\circ}$ & $.1 C^{\circ}$ & $.1 C^{\circ}$ & $.1 \mathrm{C}^{\circ}$ & $.1 C^{\circ}$ & No compromise on resolution \\
\hline Repeatability & $0.2 \mathrm{C}^{\circ}$ & $.5 \mathrm{C}^{\circ}$ & $.2 \mathrm{C}^{\circ}$ & $.2 \mathrm{C}^{\circ}$ & $.2 \mathrm{C}^{\circ}$ & $.2 \mathrm{C}^{\circ}$ & $.2 \mathrm{C}^{\circ}$ & $\begin{array}{l}\text { High repeatability reduces } \\
\text { redundant sensors and } \\
\text { measurements }\end{array}$ \\
\hline $\begin{array}{l}\text { Requires } \\
\text { calibration of } \\
\text { individual } \\
\text { sensors }\end{array}$ & No & Yes & Yes & No & No & Yes & Yes & $\begin{array}{l}\text { Eliminates individual sensor } \\
\text { calibration which is costly, time } \\
\text { consuming, and possibly } \\
\text { hazardous }\end{array}$ \\
\hline Optical losses & Low & Low & High & High & NA & NA & NA & $\begin{array}{l}\text { Single fiber minimizes losses, } \\
\text { increases accuracy, } \\
\text { repeatability }\end{array}$ \\
\hline $\begin{array}{l}\text { Low thermal } \\
\text { conductance }\end{array}$ & Minimal & Low & Minimal & Minimal & Moderate & Moderate & $\begin{array}{l}\text { Moderat } \\
\mathrm{e}\end{array}$ & $\begin{array}{l}\text { Measurements do not affect } \\
\text { process temperature }\end{array}$ \\
\hline $\begin{array}{l}\text { Susceptibility to } \\
\text { electromagnetic } \\
\text { interference }\end{array}$ & Virtually none & $\begin{array}{l}\text { Virtually } \\
\text { none }\end{array}$ & $\begin{array}{l}\text { Virtually } \\
\text { none }\end{array}$ & Virtually none & High & High & High & $\begin{array}{l}\text { Not limited to applications } \\
\text { without high EM fields, so } \\
\text { useable in motors, power } \\
\text { generation equipment, bio- } \\
\text { remediation techniques, etc. }\end{array}$ \\
\hline $\begin{array}{l}\text { Transmission } \\
\text { Losses }\end{array}$ & Low & Low & Moderate & Moderate & High & High & High & $\begin{array}{l}\text { Eliminates signal conditioning, } \\
\text { intermediate amplification, and } \\
\text { attendant inaccuracies. }\end{array}$ \\
\hline Resists corrosion & Yes & Yes & Yes & Yes & No & No & No & $\begin{array}{l}\text { Not limited to "clean" } \\
\text { environments }\end{array}$ \\
\hline
\end{tabular}




\section{1a. Describe the principal applications.}

The system is currently used in the monitoring of the chemical processes involved with the processing of nuclear materials, in thermal treatment technologies, and in bioremediation sites that use electromagnetic energy to heat the soil.

In particular, the system has been used with great success at the Savannah Power Site (a nuclear material processing facility in South Carolina) during the Department of Energy Office of Technology Development Integrated Demonstration Program, an extensive demonstration of the integration of multiple environmental remediation techniques.

Because of its immunity to electromagnetic interference and its ability to be located at considerable distance from the measuring instruments, it is especially suited to such application as power transmission lines, power generating and control equipment.

Further, two commercial licenses have been issued, both to instrument manufacturers, and one license is awaiting finalization. The issued licenses are for use in monitoring industrial chemical processes and for use in the power generation and transmission and control.

11b. List all other applications.

This remote fiber optic temperature sensor system can be used in virtually all applications where accuracy, repeatability, stability, economy, and simplicity are required.

Because it is corrosion-resistant, it can be used in chemically corrosive applications, such as food processing, petrochemical processing, nuclear processing plants, paper plants, and the like. Because it does not require either calibration or recalibration, and because its simplicity lends reliability and little need for maintenance, it is well suited to remote or inaccessible locations, such as underseas, geological studies, or space applications.

\section{1c. List all potential applications.}

Virtually the only limits to the use $r$ system is in environments where temperatures exceed the melting point of the probe, sensor, or fiber optic components. Such temperatures might be found in steel or other foundry applications, and in fusion or other high energy research applications. 


\section{Summary.}

Our fiber optic temperature measurement sensor and system is a major improvement over methods currently in use in most industrial processes, and it delivers all of the attributes requiredsimplicity, accuracy, and cost efficiency-to help improve all of these processes.

Because temperature is a basic physical attribute of nearly every industrial and commercial process, our system can eventually result in significant improvements in nearly every industrial and commercial process.

Many finished goods, and the materials that go into them, are critically dependent on the temperature. The better the temperature measurement, the better quality the goods will be and the more economically they can be produced.
The production and transmission of energy requires the monitoring of temperature in motors, circuit breakers, power generating plants, and transmission line equipment. The more reliable and robust the methods for measuring these temperature, the more available, stable, and affordable the supply of energy will become.

The world is increasingly realizing the threats to health and safety of toxic or otherwise undesirable byproducts of the industrial economy in the environment. Cleanup of such contamination often depends on techniques that require the constant monitoring of temperature in extremely hazardous environments, which can damage most conventional temperature sensors and which are dangerous for operating personnel.

Our system makes such monitoring safer and more economical. 
13. Chief Executive Officer

Name: Dr. Susan Wood

Position: Vice President and Director

Organization: Westinghouse Savannah River Company

Address: Savannah River Technology Center; 733-A

City, State, Zip: Aiken, SC 29808

Country: United States of America

Phone/Fax: $\quad$ 803/725-3994; 803/725-1660

14. Contact person to handle all arrangements on exhibits, banquet, and publicity.

Name: Ellen L. Smith

Position: Communicator

Organization: Westinghouse Savannah River Company

Address: $\quad$ Savannah River Technology Center; 773-A

City, State, Zip: Aiken, SC 29808

Country: United States of America

Phone/Fax: $\quad 803 / 725-3731 ; 803 / 725-4704$

15. To whom should reader inquiries about your product be directed?

Name: Brian Hinman

Position: Technology Licensing

Organization: Westinghouse Savannah River Company

Address: $\quad$ Savannah River Research Campus

227 Gateway Drive

City, State, Zip: Aiken, SC 29803

Country: United States of America

Phone/Fax: $\quad 803 / 652-1860 ; 803 / 652-1898$

$1-800-228-3843$ 
Figure 1. Temperature from $-200^{\circ} \mathrm{C}$ to $600^{\circ} \mathrm{C}$ can be measured using our optical temperature probes and a simple modular measuring system.

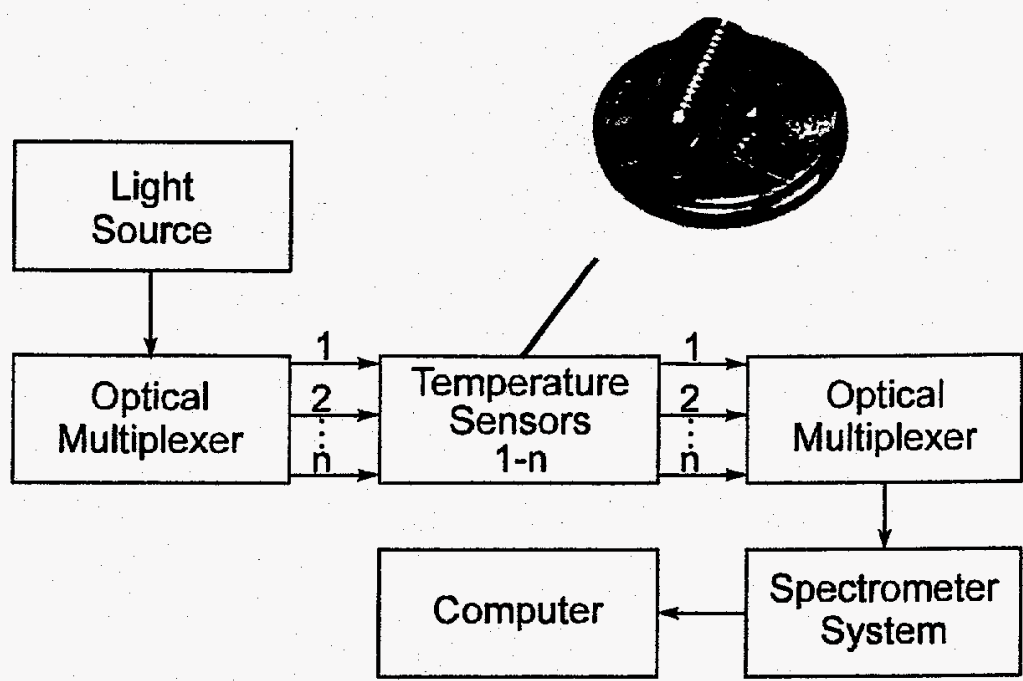

Source: U.S. Patent 5,384,396. Method and Apparatus for Optical Temperature Measurement. 
Figure 2. Temperature measurements begin with the absorbance spectrum of the sensor material. Constants are derived using one of two analytical methods: Absorption Spectrum Method or Double Ratio Absorbance Method.

Absorption Spectrum Method
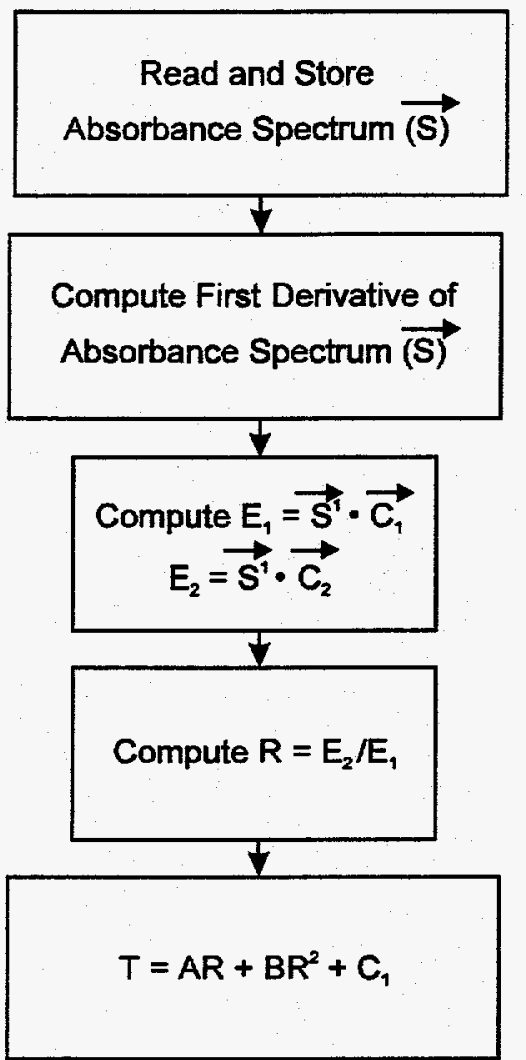

Double Ratio Absorbance Method

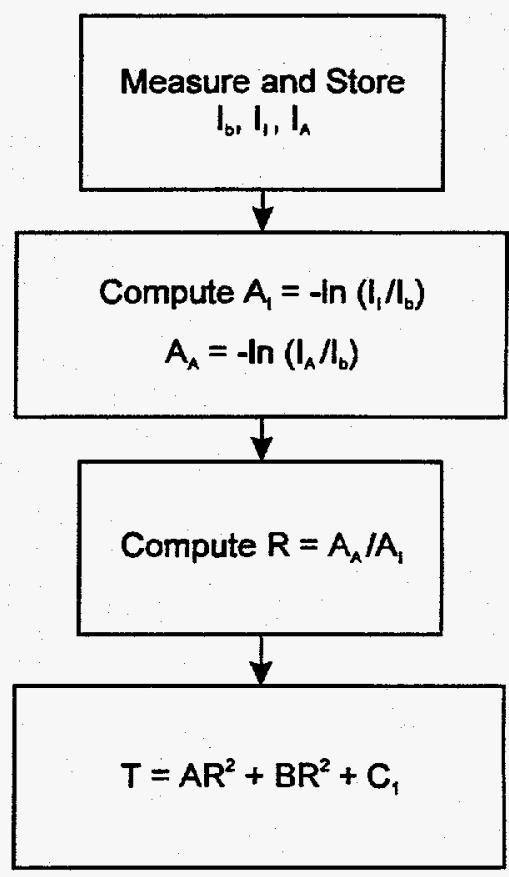

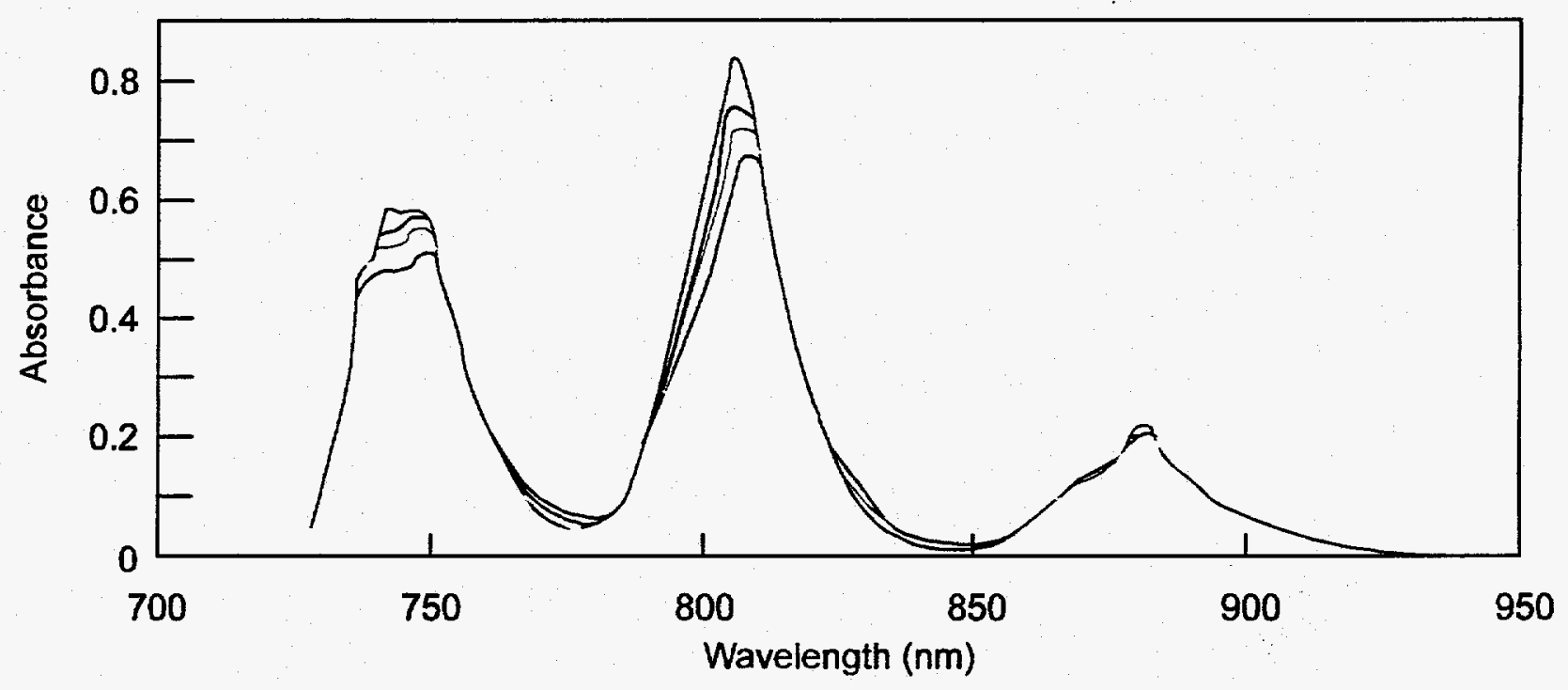

Source: U.S. Patent 5,384,396. Method and Apparatus for Optical Temperature Measurement. 
Appendix A

List of Additional Developers

Submitter's name: William S. Prather

Submitting organization: Westinghouse Savannah River Company

Address:

Savannah River Technology Center

City/State/Zip/Country: Aiken, SC 29808 (USA)

Phone/Fax

Submitter's name: $\quad$ Ronald R. Livingston

Submitting organization: Westinghouse Savannah River Company

Address:

Savannah River Technology Center

City/State/Zip/Country: Aiken, SC 29808 (USA)

Phone/Fax 


\section{Appendix B \\ List of Supporting Documentation}

1. "Sensor Technology," Westinghouse Savannah River Company, Savannah River Site, Aiken, South Carolina, 29808, WSRC-TR-93-607, page 5 only.

2. U.S. Patent 5,384,396. Method and Apparatus for Optical Temperature Measurement. Filed November 20, 1992. Granted September 20, 1994.

3. "Savannah River Technology Center Deploying Photonics for Environmental Restoration," Federal Lab Laser Tech Briefs, February 1995. 